\title{
A brief history and the possible future of urban energy
}

\section{systems}

Paul Rutter ${ }^{1}$ and James Keirstead ${ }^{2, *}$

${ }^{1}$ Visiting Professor, Dept of Chemical Engineering, Imperial College London, SW7 2AZ

${ }^{2}$ Lecturer, Dept of Civil and Environmental Engineering, Imperial College London, SW7 2AZ, tel:

+44 (0)207594 6010, j.keirstead@imperial.ac.uk

* Corresponding author

\begin{abstract}
Modern cities depend on energy systems to deliver a range of services such as heating, cooling, lighting, mobility, communications, and so on. This article examines how these urban energy systems came to be, tracing the major transitions from the earliest settlements through to today's fossil-fuelled cities. The underlying theme is "increasing efficiency under constraints" with each transition marked by increasing energy efficiency in service provision, increasing per capita energy use, increasing complexity in the energy system's structure, with innovations driven by a strategic view of the overall system, and accompanied by wider changes in technology and society. In developed countries, the future of urban energy systems is likely to continue many of these trends, with increased efficiency being driven by the constraints of climate change and rising fuel prices. Both supply and demand side technologies are discussed as potential solutions to these issues, with different impacts on the urban environment and its citizens. However in developing
\end{abstract}


countries, rising urban populations and access to basic energy services will drive the next transition.

Keywords: Urban energy systems, history, transitions 


\section{Introduction}

Urban energy systems represent the "the combined processes of acquiring and using energy" to meet the energy service demands of an urban population (after Jaccard, 2005: 6). Historically these needs were relatively simple, comprised largely of space heating and cooking requirements. However the activities of a modern city are supported by a diverse range of energy services: heating and cooling for buildings, lighting of both indoor and outdoor spaces, electric power for appliances, mobility services, communications, and so on. Recent research has demonstrated that cities account for two-thirds of global primary energy demand, a figure expected to rise to $73 \%$ by 2030 , and in turn, these demands account for over $70 \%$ of global $\mathrm{CO}_{2}$ emissions (IEA, 2008). Cities are therefore integral parts of the modern energy system and at the forefront of efforts to shift from fossil fuels to a more sustainable footing.

The story of how modern cities came to be powered largely by fossil fuels is instructive for understanding future transitions. Briefly, the earliest urban energy systems developed from the need to supply settlements with food and fuel. Prior to settled living, itinerant hunter-gatherers collected food and fuel as they travelled over large areas, moving as necessary to find these materials. Even small settlements of a few inhabitants would have had little impact on the capacity of the surrounding environment. However larger populations would have eventually exhausted the ability of the immediate environment to supply sufficient food and fuel. For example, Johnson et al. (2004) and Samuels \& Betancourt (1982) estimate that the 
low density woodland in parts of the Southwest USA would have been completely depleted in a few generations by the pre-Hispanic villagers. The fact that many successful early towns and cities were located on navigable rivers or coasts suggests that overcoming such constraints was vital to the development of urban energy systems. By collecting food and fuel from a large hinterland and transporting it affordably to the city, local production constraints could be overcome and this system, based primarily on manual and animal power, was at the heart of all urban energy systems from $3000 \mathrm{BC}$ to the advent of the railways and canals in $18^{\text {th }}$ century Europe. However as Industrial Age cities grew into their millions, the manual distribution of sufficient energy supplies to individual urban households and establishments became difficult, opening the way for early experiments with locallyproduced and distributed gas and electricity, often using imported feedstocks. By the $20^{\text {th }}$ century, these local energy solutions were unable to service the scale of energy consumption and urban development, and cities gradually became linked together in national gas and electricity grids to overcome these inefficiencies.

These shifts, their drivers and their consequences, are summarized in Table 1. It suggests that past energy transitions have been slow, taking decades or even centuries (Fouquet, 2010), and that in the urban environment, they seem to follow a pattern of "increasing efficiency under constraints". In other words, as the consumption patterns of one energy system begin to create substantial environmental, social or financial burdens, market and government pressure has motivated a switch to more efficient technologies and new alternatives. In this article, we examine these transitions by providing a short history of urban energy 
systems to date. While other researchers have considered this issue from a national perspective (Smil, 1994; Fouquet and Pearson, 1998), we adopt an urban viewpoint in order to assess the interactions between highly-concentrated local energy demands and often diffuse energy supplies. Although the focus is largely upon Western Europe, and London in particular, a range of examples from different countries and energy sectors will be used. Finally, we discuss the key themes driving these historic transitions and evaluate their relevance to the future ambitions for lowcarbon energy-efficient cities.

\section{The transition from hunter gatherer to settler}

Urbanisation is a relatively recent phenomenon that did not occur until 40,000 years or so had elapsed since our immediate ancestors, Homo sapiens, migrated out of the African continent and into Asia. As the climate warmed, the ice receded and the human population increased. A hunter-gatherer group requires a large range to supply it with food, with each individual needing several square kilometres of land depending upon the availability of game. Food supply may have been supplemented by the development of cultivation amongst foraging hunter-gatherers and herding amongst hunting cultivators (Tudge, 1998; Fuller, 2006). According to Keeley (1997), as the available hunter-gatherer range diminished due to the increasing population, frequent skirmishing occurred between family groups and tribes resulting in significant mortality amongst adult males.

Coincidently perhaps, archaeologists date the first permanent settlements to this period. The transition from hunter-gatherer to urbanite was likely to have been a gradual process, perhaps beginning with summer and winter camps. It has also been 
suggested that hunter-gatherers and settlers coexisted for a time, although as Keeley also points out it is unlikely that relations between the two were peaceful.

Settlements appeared at different times in the five separate cradles of civilisation: the Fertile Crescent, Egypt, the Yellow River basin, Meso-America and Peru. Settled communities were able to devote time to domesticating herd animals and to tend gardens containing favoured crops. Settled communities also had children more frequently since they were not constantly on the move (Diamond, 1998). The advantages of living in permanent settlements soon outweighed the old huntergatherer way of life and the transition from nomad to settler spread.

The first formal energy systems likely co-evolved over this period with changes in diet and agricultural practice. Possibly as early as 2 million years ago, our ancestors advanced from simply using fire to keep warm, to cooking food (Wrangham et al., 1999). This enabled them to increase their diet to include roots and vegetables that were otherwise unpalatable or even toxic and tenderising meat that would have been at best indigestible and at worst poisonous. Fire also gave our ancestors the ability to convert dried biomass at will into the means of keeping warm, providing light, clearing scrubland to improve pasture for the grazing animals they hunted, hardening wooden spears and eventually converting clay into a hard material that would hold liquids. This required a basic energy system to be put in place, consisting of fuel gathering and storage together with simple hearth technology to ensure that the heat from burning fuel could be used effectively. Although recent research has reduced the estimated time between early human use of natural fire and their ability to make fire at will by producing sparks from flint 
(Alperson-Afil, 2008), it is likely that considerable efforts were taken to ensure that a fire once lit, or collected from a natural source such as a lightning strike, did not go out.

\section{Early urbanisation}

About 10,000 years ago life in early settlements, such as Catalhoyuk in Anatolia and Abu Hureya in Syria, was not very different from that of the hunter-gatherers. There was little cooperation between family groups; each hunted and gathered independently and tended their gardens for the few fruit and nuts that they had learned to grow by observing the plants that appeared in their old campsites. The population grew rapidly since women could have children more frequently, even though infant mortality probably increased due to infectious diseases that would have spread more easily through settled communities.

Successful settlements require sustainable sources of water, food and fuel for cooking and warmth. Management of the amount of land allocated to food and fuel production with a growing population was challenging, exacerbated in many cases by the impact of forest clearance on water catchment and drainage. Gradually however, the weight of numbers would have had an impact on the surrounding environment. Wood and combustible biomass would have been increasingly difficult to find close to the settlement. Timber for building huts would also have become scarce and would have needed to be transported over increasing distances.

Archaeologists and historians list many examples of once powerful settlements and even cities that fell into ruin because of the denuded land's inability to sustain the population (e.g. Diamond, 2005). 
Around 5,000 years ago (3000 BC) large towns and cities such as Ur, Uruk and Lagash appeared in Mesopotamia, the strip of land between the rivers Indus and Euphrates in modern Iraq. These drew upon the surrounding villages for food and fuel, which were either traded for manufactured goods made in the cities or paid as tribute. Importantly, most of these cities were located on navigable rivers that provided a low cost method of bringing bulky fuel wood from the surrounding countryside. More than 4,000 years later, in $13^{\text {th }}$ century London, this critical part of the energy system remained unchanged as fuelwood was gathered from estates surrounding the Thames, both upstream and downstream, loaded into barges and brought into London to be sold on wharves that still bear the names of their old trade. Rome depended upon a similar system some thousand years earlier and it is reasonable to suppose that a city such as Ur, which Gates (2003) estimates to have had a population of 12,000 people some 4,000 years ago, employed the same energy supply logistics. Various estimates exist for the amount of wood required for heating and cooking per person per year. At the time of Ur a reasonable estimate might be $0.75 \mathrm{~m}^{3}$ compared to $1.5 \mathrm{~m}^{3}$ in $13^{\text {th }}$ century London (Galloway et al. 1996) and 1 to $1.5 \mathrm{~m}^{3}$ in $4^{\text {th }}$ century Rome (Williams 2003 ). It is estimated that wood use in communities which still depend upon biomass for domestic heating and cooking falls between 0.5 and $2 \mathrm{~m}^{3}$ per person per year depending upon factors such as climate. A village field plan proposed for Ur by Postgate (1994) suggests that the raised dykes along the river Euphrates would have been used to grow sustainable fuelwood possibly through coppicing (there is evidence for this which dates back to 4000 BC in Britain (Rackham, 2010)), whilst the easily irrigated land below the 
dykes would have been devoted to crops. Harvested wood and possibly other biomass, for example, reeds or straw would have been loaded into boats and transported by river to be unloaded at the wharves in Ur. A simple calculation suggests that managed woodland extending $28 \mathrm{~km}$ along a strip $1 / 2 \mathrm{~km}$ wide on both sides of the river in both directions would have been sufficient to supply the 8,000 people of Ur. For $13^{\text {th }}$ century London, estimates by Galloway et al (1996) show that there was more than enough sustainable woodland in the home counties to supply the population of 40,000 .

Whilst combustible biomass provided heat, humans and animals were the predominant sources of mechanical power. The prehistoric earthworks and stone monuments and the great Mediterranean, Asian, African, North and South American cities of the ancient world were all constructed using human or animal muscle power. Innovative machines designed to assist muscle power, such as the shaduf for lifting water and the rotary quern, began to appear in $1600 \mathrm{BC}$. The Romans used human and animal treadmills extensively and similar machines were still operating as recently as the $19^{\text {th }}$ century in London's docklands (Smil, 1994). Land transport depended upon draft animals or humans. The great trade empires of the Anazazi in the Four Corners region of the USA used human runners since even pack animals were unknown. The Inca empire stretching more than $3,500 \mathrm{~km}$ down the west coast of South America was served by a network of roads designed for humans and llama used solely as pack animals (Parry, 2005).

Although the scale of energy consumption and associated technologies improved, urban energy systems consisted largely of biomass either burned in a 
hearth or fed to animals as food up until the $13^{\text {th }}$ century. However to complement biomass resources, cities and their economies were also turning to other renewable energy sources such as wind and water. Sails had been known since 4,000 BC (Egypt) and were used extensively on the Nile. The use of sails to capture the power of the wind accelerated trade round the Mediterranean basin and also facilitated invasion and war. Water power was harnessed in this area around $500 \mathrm{BC}$ and was rapidly brought into use for grinding cereals eliminating many thousands of painful repetitive human hours of toil. Water power also powered a variety of machines used, for example, in blacksmithing, tanning, fulling, and wood turning. The first wind turbines were probably invented around AD 900 in the Middle East but it was not until the $14^{\text {th }}$ century that windmills began to be widely used in Europe. Although water wheels and eventually windmills were capable of providing about 25 times more power than a horse or 50 times more than a man, they provided less than $10 \%$ of the total power capacity available from humans and animal muscles until about 1800 when steam began to dominate inanimate sources of power (Smil, 1994; Wrigley, 2010).

Whilst many aspects of $13^{\text {th }}$ century life in London would have seemed extraordinary to a visitor from 2000 BC Ur, the energy system would have been familiar. For about 3,500 years very little had changed in the urban energy system. Life in these cities moved slowly and depended upon what resources could be grown and harvested over a limited number of years, and what could be carried on a person's back, by horse and cart or by boat from local hinterlands. Improvements in technology and the increased use of renewables meant that the energy consumed per 
capita doubled from 15 GJ per capita per year in 1500 BC Egypt (Smil, 2010) to about 30 GJ per capita per year in $17^{\text {th }}$ century (Malanima, 2006) based on food for human beings, fodder for animals and firewood. However this was to change radically as Europe emerged from the horrors of the Plague during the $14^{\text {th }}$ and $15^{\text {th }}$ centuries.

\section{Biomass to coal}

The next major transition was from local resources harvested instantaneously or within a few years to the use of vast reserves of fossil fuels, representing hundreds of years of equivalent energy in a compact form. Coal was the first fossil fuel to enter the urban energy system in significant quantity. By 1450 London was a rapidly growing cosmopolitan city drawing its wealth from England's wool trade. Small amounts of coal had been in use in London since 1100 and perhaps earlier. Known as 'Sea-coles' it was used to provide the high temperatures needed in forging iron, lime manufacture and evaporating sea water to prepare salt. The name referred not only to the fact that it was imported by sea from the Tyne, but also because it was often found washed up on the beaches of Northumberland. Indeed fossil fuels were reasonably well-known and used where they could be easily gathered or seeped above ground. The Chinese are credited with the first use of natural gas which was piped from natural outlets using hollowed out bamboo for use in the production of salt. Even though the amount of coal burned in the late $13^{\text {th }}$ century London was relatively small, the smell still incurred the wrath of Edward I who banned its use, threatening to confiscate the forges where it was used. The use of coal in London 
persisted however, causing a second monarch, Elizabeth I to complain nearly 300 years later.

Between 1520 and 1550 London's population grew from 55,000 to 120,000. This rate of growth put such a strain on the previously sustainable fuel wood supply that it began to fail and the price of wood at the London wharves increased sharply. The Domesday Book estimated that about 15 per cent of Britain was covered in forest in the $11^{\text {th }}$ century, but by the end of $16^{\text {th }}$ century this had diminished to about $6 \%$ (Allen, 2010). This was largely due to woodland clearance around large towns and cities to produce agricultural land for the growing population. The issue was particularly acute in the case of London where the increase in distance required to carry wood overland from the ring of woodland that was now 20 to 40 miles away resulted in a doubling of the price of wood by 1550 and a trebling to 12 grams of silver per GJ one hundred years later (Allen, 2010).

The price of coal however, remained low at between two to four grams of silver for the same heating value. This discrepancy was almost entirely due to the cost of transport. The weight of wood that could be cut by a woodsman in one year was similar to the amount of coal that could be dug by a coal miner (Rackham, 2010). The difference in calorific value coupled to the fact that coal was only transported a short distance from the mines on the Tyne to ships that took it to London meant that, by the time both fuels reached the wharves in London, the cost of fuel wood was much higher than that of coal per GJ.

Whilst the cost differential made coal an attractive option there was considerable resistance to its use. It took time for builders to develop the chimneys 
and grates that enabled coal to be burned without filling rooms with smoke. Most of this experimental work was done in London before the Great Fire of 1666 but much of the knowledge gained must have been put to good use during the subsequent rebuilding and by 1700 , over half of Britain's coal consumption was for domestic heating (Allen, 2010). The commercial use of coal also increased as bakers and brewers developed technology to prevent their products being tainted by coal smoke. Fears of impaired quality caused glass manufacturers to continue to burn wood in their furnaces until its use was banned by Parliament in 1615. This caused Sir Robert Mansell to move his glass manufacturing plant to Newcastle and perfect a new covered crucible (Godfrey, 1975). Requiring about the output of approximately oneseventh of English woodlands, the 'iron masters' came under considerable pressure to limit the amount of wood they consumed for charcoal from a statute of 1580 which prohibited ironworks using charcoal made within 22 miles of outer London (Rackham, 2010) but it took a further century for iron manufacture to turn to coal when Abraham Derby developed a coke smelting process and another 50 years or so of improvements before coke iron production started to replace charcoal.

The move away from relatively short rotation biomass fuels (e.g. a two-year rotation willow for kindling, eight to ten-year rotation coppiced poles, together with wood residues from the construction industry) to coal took even longer in continental Europe. Whilst there had been relatively little government intervention in controlling fuel prices in London, the situation in Berlin was different. When that city's population began to grow rapidly at the end of the 17 th century, wood prices increased and supplies became scarce. State edicts enacted between 1691 and 1693 
to lower wood prices were ineffective and a central firewood administration was established in 1694 to regulate the private wood trade (Sieferle, 2001). In 1702 in Konigsburg, firewood was rationed according to the 'rank' of the household. Wood conserving stoves were known as early as 1325 but in 1763 an official contest took place in Prussia to design a domestic stove that consumed minimum quantities of wood. Iron production had enjoyed the use of dedicated wood supplies in parts of Germany but this privilege was removed in 1783 with disastrous results on their ability to export cheap iron. By the end of the $18^{\text {th }}$ century the state authority that maintained the cheap price of fuel wood in Berlin allowed the price to rise and also began to sell coal at a loss to promote its use. In Silesia the use of coal was also increasing rapidly in spite of the widespread propaganda against the use of coal during the first half of the $18^{\text {th }}$ century. Authoritative articles and pamphlets had been published in Germany and France describing the health hazards of burning coal. One claimed that one-third of all the inhabitants of London died of wasting disease and lung ailments caused through the corrosive effects of smoke from coal fires. Another obstacle to the widespread use of coal was the inland location of the coal pits and commercial centres and the lack of good navigable waterways. This meant that the price of coal was relatively high and as late as 1886 in Hamburg, Ruhr coal could not compete with imported coal from England.

Meanwhile in Britain by 1800 the consumption of coal had risen to 15 million tonnes per annum providing both domestic and industrial heat (Allen, 2010). However the English pits had a problem and, by the end of the $17^{\text {th }}$ century, many were suffering from flooding. Draining the mines was expensive and tunnelling 
drainage channels was dangerous. Many solutions were offered but most proved unworkable. In the late 1600s Denis Papin demonstrated a device to the Royal Society consisting of a piston inside a brass cylinder that was made to move by heating water in one end of the cylinder. Thomas Savery invented a device that used a vacuum created by condensing steam for draining mines. He called it 'the miner's friend' and demonstrated it before the Royal Society in 1699 . However it had a number of practical disadvantages and was not commercially successful. Barbara Freese (2006) notes that one observer complained in 1708, "every year more mines are left unwrought or drowned for want of such noble engines or methods that are talked of or pretended to". The stage was set for Thomas Newcomen, who built a much larger piston with a separate steam boiler and was able to convince the mine owners that steam power was a practical proposition. His first 'fire' engine was installed in a mine in 1712 and was much cheaper to run than the 50 horses it replaced even though it was extraordinarily inefficient. Newcomen's engines proved popular and although one was built to pump water from the Seine to supply Paris, in practice it was uneconomic to operate them anywhere except coal mines where coal was cheap and unmarketable 'small coal' was abundant. The increase in coal production made possible by Newcomen's engine resulted in considerable expansion of mining infrastructure including the double track system to carry coal more efficiently. At the same time Darby's process which substituted coal for charcoal in iron smelting allowed the use of cast iron to replace brass and copper in the manufacture of cylinders and boilers reducing the cost of Newcomen's engines. The decisive shortcoming of Newcomen's engine was that it only produced power on the 
downstroke which seriously limited its use. This was remedied in 1775 when Watt designed an enclosed cylinder in which steam could be admitted not only to power the downward stroke but also the upward stroke; a patent was granted to Watt in 1782.

Experiments using steam engines to power ships had begun in 1778 in France and a steamboat service linking Philadelphia to Trenton in New Jersey along the Delaware river was established by John Fitch in 1790. The use of steam to power vehicles on land however, was a more serious challenge. The best any atmospheric steam engine could do even with iron rails was to move along a level trackway. Watt had already realised that high pressure steam was the answer but was inhibited by the potential danger of exploding boilers. It was left to Trevithick to bring together all the improvements in valves, boiler construction, and cranks to produce a working prototype steam powered road vehicle which he demonstrated just outside his home town of Cambourne in Cornwall, on Boxing Day 1801. The following year he was granted a patent entitled, 'Steam engines - improvements in the construction thereof and Application thereof for driving carriages' (Crump, 2007). Stephenson's Rocket appeared in 1825 and was operated on the Stockton to Darlington railway and a new age for transport began which was to have a resounding impact on city life as passengers could now travel further for the same time commitment (or rather, physical energy expenditure (Kölbl and Helbing, 2003)).

Although wind and water played an important role in the early industrial age, for example by providing the means to mechanise textile manufacture and move it from 
rural cottages to the factories of the Lancashire and Derbyshire dales, these sources had relatively little impact on the overall urban energy supply. Water power in particular was only possible where there was a reliable supply of flowing water of sufficient volume to turn the water wheels. Steam does not suffer from such constraints and allowed factories to be located in large population centres with access to navigable waterways or later on, to railways.

\section{The rise of networked energy systems in urban Britain}

The impact of the Industrial Revolution spread throughout Europe, the New World and eventually more widely, with each region developing its own route and pace towards what we now recognize as a modern city. A comparative study of the rates of penetration of energy technologies and the consequent changes on society cannot be dealt with here; instead we will focus on the development of complex networked energy systems in Britain as an example of at least one route to the modern urban environment. In this case, the social and economic changes brought about by the Industrial Revolution led to a need to restructure the provision of urban energy services, specifically via the use of network infrastructures.

The 18th century saw an explosion in population and city growth in Britain. With the exception of London, the cities of the south and east that had enjoyed a dominant position due to trade with the northern European states declined in importance and the ports and cities of the industrial north and west increased in size and wealth. In 1835, Manchester was described by Alexis de Tocqueville, the French commentator as having "a sort of black smoke which covers the city. Under this half daylight, 300,000 human beings are ceaselessly at work. The homes of the 
poor are scattered haphazardly around the factories. From this filthy sewer pure gold flows. In Manchester civilised man is turned back almost into a savage" (Freese, 2006). England and Wales were ahead of the rest of Europe in the pace of urbanisation. By 1860 about $50 \%$ of the population was urbanised compared to about $25 \%$ of the populations of the Netherlands, Belgium and Italy with France at around 18\% (Malanima and Volckart, 2007).

The industrialisation of the growing towns and cities was greatly facilitated by improvements in methods of transport, notably the railway network. The railways revolutionised land transport and allowed fresh food, fuel and people to be brought into the centre of cities on a daily basis at a relatively low cost. London's Euston station was opened in 1837. Mainline stations operating from London were prohibited from the centre of the city because Parliament was concerned about the disruption their construction would cause to the city but even so, at least 100,000 Londoners had their homes destroyed. By 1850 in addition to commuters brought into London by train, at least 15,000 people travelled to work in London by paddle steamer along the Thames. The centre of London became so congested in that Charles Pearson, a City of London solicitor, set out plans in 1845 for an underground railway to alleviate the problem. After a number of false starts, in part due to reluctant investors, construction began in 1860. Sadly Pearson died in 1862 a year before the first underground railway was opened between Farringdon and Paddington (Wolmar, 2004). This relied on steam engines for motive power with chimneys to allow smoke and steam to escape from the tunnels. These technological innovations naturally increased the demand for transportation energy, but also had a 
significant impact on the energy demands of other sectors. Commuters were able to move out of the crowded cities into suburban homes, which were often larger requiring greater heating and lighting demands and needed to be filled with new manufactured goods (Kennedy, 2011).

The growth of urban populations also highlighted the health hazards of urban living and Parliament responded by passing a number of Town Improvement Acts during the 18 th and early 19 th centuries. These compelled towns to provide clean water and to clean, pave and light the streets. Lighting in particular was an important application that helped establish networked urban energy services.

Better street lighting was needed to improve the safety of people commuting in and out of the city and to effectively lengthen the working day. Initially streets were lit by means of 'parish lamps' consisting of a small tin vessel half filled with fish oil containing a piece of cotton twist as a wick (Ackroyd, 2000). Lamplighters were employed to light, trim and fill the lamps. By the end of the 17 th century oil lamps were the dominant form of street lighting but increasing demand for higher quality lighting stimulated research into better forms of illumination and from the 1770s, the Royal Society handed out many prizes and awards for lighting improvements (Fouquet and Pearson, 2006). By the early 19th century there were 35,000 lamps lighting the streets of London utilising a lighting system that had changed little for perhaps a thousand years. However, a new energy system was about to appear that was particularly suited to the urban environment.

At the end of the 18th century, William Murdoch in Britain and Philip Lebon in France were independently experimenting with the gases that were produced by 
heating coal or wood under controlled conditions. In 1798 Murdoch used coal gas to light a room in a house in Cornwall and in 1801 Lebon staged a demonstration of gas lighting in Paris (Williams, 1981). Albrecht Winzer, a German professor of commerce, was quick to realise that this provided the potential for a new method of lighting and began public demonstrations of gas lighting in London in 1804. Increasing public interest encouraged Boulton and Watt, together with Murdoch, to install six cast-iron retorts to provide the gas for lighting a cotton mill in Manchester in 1806. In the same year, Winzer who realised the commercial advantages of centrally manufactured gas that could be piped to many customers anglicised his name to Frederick Winsor and attempted to gain a government charter allowing him to form a commercial gas lighting company. His first attempt failed but in 1812 he started the Gas Light and Coke Company that would eventually control most of the London gas market. Gas lighting received Royal patronage in 1821 when the Prince Regent introduced gas for lighting the music room and banqueting hall of his pavilion at Brighton. By 1829 some two hundred gas companies had been formed and gas lighting had been installed many of the larger cities in Britain (Williams, 1981). However, there were some setbacks to the fledgling industry. An experiment with gas lighting in the newly built Houses of Parliament in 1838 was abandoned since the cost was nearly four times that of traditional wax candles (Barty-King, 1984). But in spite of early difficulties by 1849 , gas lighting provided by local gas works had been installed in 700 large towns in the UK but both the growing domestic and commercial markets for lighting were about to undergo further change. 
The domestic market was still largely dependent upon oil lamps that burned expensive whale oil, tallow candles, or rushlights, which were smelly and gave a poor light. Technical improvements to oil lamps improved their efficiency and the cost of oil lighting fell by two thirds between 1750 and 1820. The price of lighting continued to fall but by the middle of the 19 th century whales were becoming increasingly difficult to find. There was also an increasing demand for lubricants for the growing number of industrial machines. There was a clear opportunity for the development of a new source of light oil. In 1837, Baron Karl von Reichenbach and Abraham Gesner in 1847 showed that as well as gas, paraffin and other oils and chemicals could be extracted from organic solids such as coal, wood, tar and shale. Natural oil and gas seeps had been known and used for centuries so when the young chemist James Young was told about an unusual underground spring near a coal mine in Alfreton in Derbyshire that produced about 300 gallons a day of a thin treacly liquid, he had the presence of mind to carry out an analysis and discovered that it contained paraffin, naptha, light oil and a heavier lubricating oil. It also burned "with a brilliant illuminating power". Following his discovery, he patented a process in 1850 describing how to extract coal oil and 'crack' it into its component substances (MSSO, 2012). A year later, James 'Paraffin' Young opened what was probably the world's first oil refinery at Inchgate on the outskirts of Bathgate in central Scotland. These innovations soon spread beyond the lighting sector, and paved the way for oil-based transport of many modern cities. 


\section{The electric age}

Lighting produced by either a gas or oil flame had improved considerably since the days of candles and rushlights but suffered from a number of disadvantages. It was a potential fire hazard, the flames produced soot, and light levels were low especially outside. Gas was expensive and slow to penetrate the domestic market and by the end of the 19th century, it was to be challenged by electricity. In contrast to gas, electric lighting offered convenience and cleanliness, features which combined with its versatility as a power source, enabled electricity to become the major urban energy source of the twentieth century.

Inventors were quick to understand and utilise the connection between magnetism and electricity demonstrated by Faraday in 1831 . The first electric motors appeared in 1837 and the electric telegraph was commercialised in 1844. The first practical electric lighting system was demonstrated by Jablochkoff in Paris and London in 1878. This consisted of an electric arc struck between two carbon electrodes. 1878 also saw the first floodlit football match when Sheffield Football Association played the first evening match under 8,000 candle power provided by two Siemens generators (IET, 2012). After a demonstration of the Jablochkoff 'candle' in a concert hall in New York, the New York Times of 10 November 1880 proclaimed that one candle can replace six gas burners and yield five times more light. However, in common with other electrical devices of the time the lighting system required its own generating system, in this case consisting of a steam engine and two generators. Edison had already worked on a number of electrical devices and had sufficient wealthy backers and valuable patents to finance his extensive 
workshop and laboratory at Menlo Park, New Jersey. He realised the advantages of Winzer's central gas production system and set about designing an equivalent electrical generating system, which provided electricity to customers through copper wires (Patterson, 1999). Edison also attempted to develop an electric light source that could be used in enclosed spaces more easily than the electric arc. Both he and the English physicist Swan arrived at a practical solution to the problem independently in 1878 and by 1881 twelve hundred of Swan's bulbs were used to light the Savoy theatre in London. Edison in turn, exhibited his lighting system at the Paris exhibition in 1881 and at Crystal Palace in London a year later. It was the success of his 'electric bulb' that enabled Edison to commercialise his integrated power and lighting systems by building power stations at Holborn in London and Pearl Street in Manhattan. The Pearl Street station fed steam from coal-fired boilers to six generating sets each producing 1000 kilowatts, enough to light the one square mile of New York City. The British electricity industry boomed between 1870 and the early 1880 s with many entrepreneurs entering the business and considerable investment attracted by new companies formed to supply electrical equipment and power (Shiman, 1993).

The UK government both encouraged and hindered the development of the fledgling gas and electricity industries. In 1860 the Metropolis Gas Act allowed existing gas companies to have monopolies in the districts where they operated and in 1882 the Electric Lighting Act gave similar monopolies to electricity companies, only this time a so-called 'scrap-iron' clause was included. This allowed the companies to have the monopoly supply for a specific district for 21 years after 
which the company would be subjected to compulsory purchase at a value based on its material assets. Hughes (1983) argues that, in the opinion of private enterprise, the 1882 Act stifled the development of the British electricity supply companies. However Hannah (1979) states that investors were deterred by exaggerated claims for both arc lighting and incandescent lighting, pointing out that at least one and a half million pounds had been subscribed by a prematurely enthusiastic investing public, mostly on worthless patent fees for often fraudulent inventions, legal expenses and promoters' profits. In spite of the frantic activity in the 1880 s the electricity boom soon turned to bust and Britain fell far behind the USA in installing and using electric power for lighting and other purposes. In 1890 there were 235,000 arc lights in use in the US, and streets in virtually every American city were lit with bright lights whereas in Britain there were only 700 arc lights on the streets (Shiman, 1993).

The gas industry put up a spirited fight to retain its position in the lighting market helped by the invention of the incandescent mantle by Auer von Welsbach which tripled the efficiency of gas lighting and improved its quality (Fouquet and Pearson, 2003). However, Winzer's original patent had envisaged the use of gas for both heating and cooking as well as lighting but it was not 1879 that in evidence to a House of Commons Committee, Magnus Ohren of the Crystal Palace District Gas Company testified "new firms are embarked in this business and all sorts of gas apparatus are now made by the thousand." These included gas cookers, and gas boiling rings. Persistent fears (reminiscent of coal) that cooking with gas might taint food and injure health were refuted in The Lancet and London Hospital adopted gas 
cooking for both patients and staff (Williams, 1981). The reluctance of British towns and cities to adopt electric lighting seemed to be based primarily on cost and fears about the implications of granting a monopoly to an electric company. One local authority in London announced it was taking bids for electric lighting in order to force gas prices down (Shiman, 1993) but in the US, there seemed to be more public interest in getting bright electric lighting for their urban centres than cost.

The next century saw both the gas industry and the electricity industry diversify from their primary market of lighting. But first substantial rationalisation took place in both industries. This was to have a considerable impact on the way the urban energy supply system was both managed and configured. At the beginning of the 20th century there were over 800 gas businesses supplying the UK market and by 1935 the gas supply industry provided employment for about 230,000 people, supplied about a quarter of the population, and had capital assets worth about $£ 200$ million (Williams, 1981: 68). By 1950 about $80 \%$ of British dwellings were connected to a gas supply (Fawcett et al., 2000) but the industry encountered strong competition from electricity until its fortunes recovered with the discovery of natural gas in the North Sea. Similarly, by 1920, the UK electricity system consisted of over 600 suppliers owned both by local authorities and private companies acting independently resulting in about $75 \%$ more generating plant throughout the country than was required to supply peak demand. As an example of the extraordinary diversity that had grown in the industry, by 1918 in London alone there were 70 authorities, 50 different types of system, 10 different frequencies and 24 different supply voltages (Butler, 2001). 
These infrastructures were no longer fit for purpose and in $1925 \mathrm{a}$ government report produced by Lord Weir recommended that electricity generation should be restricted to a limited number of power stations connected to a national grid. This resulted in the 1926 Electricity Supply Act and the formation of the Central Electricity Board (CEB). By 1935 nearly 3000 miles of primary transmission lines and 1200 miles of secondary lines had been built. The grid finally reached all parts of the country by 1945 . One of the functions of the post-war CEB, nationalised under the Electricity Act of 1947, was to accelerate the use of electricity in industry. It took much longer to nationalize the gas industry. The Gas Regulation Act of 1920 was the first to allow the exchange of gas from one undertaking to another but this was complicated by the demand pattern for gas such that by 1938 only $0.4 \%$ of all gas sold was via this type of exchange. However, the implied threat of nationalization accelerated the amalgamation of undertakings into holding companies. The 1939-45 War caused valve systems to be installed between adjacent undertakings in London, Liverpool and Manchester so that supply could be continued and sections of main isolated for repair. The UK gas industry was finally nationalized in 1948. However, the story was not over. Britain converted its gas supply from coal gas to natural gas between 1967 and 1977 at a cost of $£ 563$ million, equivalent to approximately $£ 5-6$ billion today. One of the consequences of the conversion to natural gas was that the coal-fired municipal gas works, often located within urban centres, were no longer required. Natural gas was largely drawn from the gas fields of the North Sea and provided through a national gas grid, completed in 1978. 
By the mid 1960s, the demand for electricity for both domestic and industrial use was expanding at $7 \%$ per annum. Much larger power stations were required which consumed millions of tons of coal per annum (a $1 \mathrm{GW}$ station burns about 3 million tons of coal a year) and an enormous amount of cooling water that could only be drawn from major rivers or the sea. The grid allowed these stations to be built away from urban centres close to sources of fuel and water (Patterson, 1999).

The natural gas and electricity grids marked a radical change in the UK urban energy system. The only substantial import of fuel that now needed to be transported by road or rail into the urban centres was petrol or diesel, largely for transport. In a sense this has taken the place of the oats required for the horses and the coal for the power stations dedicated to providing electricity for the trams and underground. The energy demands for the domestic, commercial and industrial sectors of urban communities are now largely met by electricity and natural gas brought in through the wires and pipes of national grids. This has the advantage of physically removing many of the externalities of the energy system from the city (e.g. pollutants from combustion in electricity generation). However this shift also changed the 'urban-ness' of these energy systems. Whereas before energy resources were imported to each individual city from its hinterland or wider markets on an adhoc basis, cities were now stitched together as part of national energy systems

\section{The future of urban energy systems}

The transitions described so far are summarized in Table 1 and Figure 1, and they share four common features. First, each of the fuel transitions represent an intensification of energy use (Smil, 1994). Early biomass systems enabled societies 
to access energy reserves accumulated over hours, days or perhaps years in the form of animal power, wind and water renewables, and woody biomass. However fossil fuel energy systems take advantage of thousands or millions of years of concentrated solar energy, thus enabling the system to overcome the physical constraints of increasing biomass consumption (i.e. larger collection areas, longer supply chains). Each period also showed increases in per capita energy use despite technological innovations, for example through more efficient heating or lighting technologies. A good example of this is the introduction of commuting in London, which increased the demand for transport energy and also changed patterns of domestic energy consumption.

The second trend is the increasing complexity of urban energy systems. As Tainter (1988) notes, societies often solve their problems through increased organizational and technological complexity and this can be observed in the case of urban energy systems as well. Early systems relied upon biomass gathered from the local area, necessitating small supply lines and crop management strategies. The transition to coal, particularly the differences between the English experience, with its sea and canal transport, and that of continental Europe, illustrates the need to expand the physical reach of the energy system into the city's wider regional and national hinterland, requiring increased organization and coordinated supply chains. Modern electricity and gas networks take this further still, knitting cities together into a national energy system that, in the case of electricity in particular, must be managed on a near-real time basis. 
Third, urban energy system transitions often benefitted from policies to promote innovation, motivated by a strategic view of the overall system and the constraints of existing system configurations. The Royal Society lighting prizes, the Prussian competition for more efficient stoves, and the 'scrap iron' clause all demonstrate how governments and private-sector actors engaged with the energy system to ensure that it would meet their perceived long-term requirements while mitigating the downsides of current system configurations. These interventions were not always positive as established stakeholders were often reluctant or outright hostile, to shift to new technologies. Such patterns are well described in the literature on technological transitions (Geels, 2002; Verbong and Geels, 2007).

Finally, each transition of the core structure of the urban energy system did not evolve in isolation but in parallel with wider changes in society and technology. Examples of this include increased transportation speeds and rail networks facilitating urban growth, the development of steam engines for enhanced coal extraction but also motive power for factories, the use of whale oils for lubricants as well as lighting, and the role of electricity in providing enhanced communication networks in addition to more traditional energy services like heating and lighting. These highlight the importance of studying urban energy systems specifically, as cities represent the centres of social and economic change.

A final observation, clearly visible in Figure 1, is that these transitions have been occurring with increasing rapidity. As described above, $13^{\text {th }}$ century London looked remarkably similar to the earliest cities, but then the pace picked up: the transition to coal had begun in earnest by the $18^{\text {th }}$ century, the oil economy 
beginning in the late $19^{\text {th }}$ century, and the modern national grids evolving since the Second World War. As noted by Bettencourt et al. (2007), this pattern emerges because each system configuration eventually exhausts its available resources or the capacity of its supporting infrastructure and, whether through the resulting price signals or political decisions and market interventions, this scarcity facilitates the shift to a new technological system. However to date, each new energy system has been more energy intensive than the last (although drawing on a different fuel source), creating additional new pressures and suggesting that the overall pace of innovation must accelerate.

Given these observations on historical trends, what might we conclude about the future of urban energy systems? As in past systems, we can identify a number of constraints and drivers for future change. In developed countries, such as the UK, current challenges include the increasing scarcity of traditional fossil fuels, aging energy infrastructures, and concerns about climate change. Improved efficiency in the urban energy system offers one solution to this problem. Recent research on the optimized design of urban energy systems suggests that significant energy and carbon emissions savings of approximately $20 \%$ are possible with existing technology (Sugihara et al., 2004; Keirstead et al., 2011; Weber and Shah, 2011). Smart grid technologies will allow energy producers and consumers to be linked more closely, allowing the maximum value to be extracted from existing assets (for example, by carefully managing times of peak demand) and improved energy efficiency in the home also offers a way to improve the financial and environmental efficiency of energy service provision, provided that appropriate policy incentives 
can be identified (see, for example, the recent debate over the UK's 'Green Deal' (Carrington, 2012)). However, entirely new supply side technologies may also be needed. Just as in previous transitions, where the difficulties of biomass energy supply eventually led to a shift to fossil fuels, the current cost and environmental impacts of fossil fuels may lead to the increased adoption of alternative technologies like renewable energy, nuclear fission, and in the long-term perhaps nuclear fusion. To some extent, changing cost structures are already being seen with the cost of solar photovoltaics, for example, having fallen 17\% between 2009 and 2010 even when excluding government support programmes (Barbose et al., 2011).

Arguably the key question is how these innovations might affect the fabric of urban energy systems and the societies and economies they support. On the one hand, the increased use of nuclear power and large-scale renewable energy would fit well with the existing system of centralized supply, simply substituting for existing fossil fuel power sources and leaving cities in their current roles as largely passive centres of demand. On the other hand, innovations like smart grid technologies and combined heat and power must be embedded directly within the urban fabric, suggesting a return to the late $19^{\text {th }}$ century model of "local" utilities (i.e. the utility companies themselves may be national for economies of scale, but operating with a greater awareness of local energy geography). Energy service companies, which provide consumers with end services such as heating and lighting rather than raw fuels, are a potentially significant part of this shift and are actively promoted by policy makers in Europe and elsewhere (Bertoldi et al., 2006). Information and communication technologies (ICT) might also offer opportunities for new modes of 
service provision, such as integrated mobility services and online access to goods and services, potentially reducing the energy intensity of these activities but also changing the way in which people move about the city in performing their daily activities.

In contrast, the cities of developing nations are experiencing many of the same drivers seen in $18^{\text {th }}$ and $19^{\text {th }}$ century Europe. Specifically, these countries are seeing rapidly urbanizing populations, which leads to the increased demand for energy services that come with rising standards of living. Existing biomass-based energy systems will struggle to cope with these demands, and there will be a need to access new more efficient modern energy services such as electricity and fossil fuels (Leach, 1992; Chancel, 2010; Nissing and Blottnitz, 2010). A recent report by the World Energy Council (WEC, 2010) notes that many of the technologies needed for such a shift are already known; the question is how to ensure their adoption and successful use. This suggests that, in addition to the lifestyle changes that one might expect to occur with improved access to modern energy services, the institutional and market changes necessary to introduce commercial energy services and related infrastructure may have the greatest effect on these cities in general, for example, by helping to bring residents into the formal economy. For example, an electrification project in Kibera, Kenya (a large informal settlement in Nairobi) found that the installation of pre-paid meters helped to make connection fees affordable for individual households and reduce reliance on stolen electricity supplies (Mohammad, 2009). 
Looking beyond these next transitions, at least two issues must be considered when assessing the long-term futures of urban energy systems. The first is the warning of some systems analysts that increased complexity and integration may create sustainability risks in the long run (Fisk and Kerherve, 2006). Managing complexity requires resources and these flows can be difficult to maintain over time (Tainter, 1988). The second related point is whether or not energy systems innovation will continue to happen quickly enough to support the needs of a larger, wealthier global urban population in a climate-constrained environment. Each of the transitions described here have led to higher per capita rates of energy consumption, as improvements in efficiency are outstripped by increases in levels of activity and production. The question is therefore whether or not society can keep up this frenetic pace.

\section{References}

Ackroyd, P., 2000. London: the biography. Chatto \& Windus, London.

Allen, R.C., 2010. The British Industrial Revolution in Global Perspective. Cambridge University Press, Cambridge.

Alperson-Afil, N., 2008. Continual fire-making by Hominins at Gersher Benot Ya'aqov, Israel. Quaternary Science Reviews 27, 1733-1739.

Barbose, G., Darghouth, N., Wiser, R., 2011. Tracking the Sun IV: An Historical Summary of the Installed Cost of Photovoltaics in the United States from 1998 to 2010, Direct.

Barty-King, H., 1984. New Flame. Graphmire Ltd, London.

Bertoldi, P., Rezessy, S., Vine, E., 2006. Energy service companies in European countries: Current status and a strategy to foster their development. Energy Policy 34, 1818-1832.

Bettencourt, L.M.A., Lobo, J., Helbing, D., Kühnert, C., West, G.B., 2007. Growth, innovation, scaling, and the pace of life in cities. Proceedings of the National Academy of Sciences of the United States of America 104, 7301-6. 
Butler, S., 2001. UK Electricity Networks.

Carrington, D., 2012. Green deal suffers setback as loft insulations set to plummet. The Guardian.

Chancel, L., 2010. Urban energy transition in the developing world: The case of Nakuru, Kenya.

Crump, T., 2007. The Age of Steam: The power that drove the industrial revolution. Robinson, London.

Diamond, J., 1998. Guns, Germs, and Steel: A short history of everybody for the last 13,000 years. Vintage, London.

Diamond, J., 2005. Collapse: How Societies Choose to Fail or Survive. Penguin Books, London.

Fawcett, T., Lane, K., Boardman, B., 2000. Lower Carbon Futures for European Households. Oxford.

Fisk, D., Kerherve, J., 2006. Complexity as a cause of unsustainability. Ecological Complexity 3, 336-343.

Fouquet, R., 2010. The slow search for solutions: Lessons from historical energy transitions by sector and service. Energy Policy 38, 6586-6596.

Fouquet, R., Pearson, P.J.G., 1998. A Thousand Years of Energy Use in the United Kingdom. The Energy Journal 19, 1-41.

Fouquet, R., Pearson, P.J.G., 2003. Long run trends in energy services: the price and use of road and rail transport in the UK (1250-2000).

Fouquet, R., Pearson, P.J.G., 2006. Seven Centuries of Energy Services: The Price and Use of Light in the United Kingdom (1300-2000). The Energy Journal 27, 139-177.

Freese, B., 2006. Coal: A Human History. Arrow Books.

Fuller, D.Q., 2006. Agricultural Origins and Frontiers in South Asia: A Working Synthesis. Journal of World Prehistory 20, 1-86.

Galloway, J.A., Keene, D., Murphy, M., 1996. Fuelling the city: production and distribution of firewood and fuel in London's region, 1290-1400. The Economic History Review 49, 447-472.

Gates, C., 2003. Ancient cities: the archaeology of urban life in the Ancient Near East and Egypt, Greece and Rome, Ancient Cities. Routledge.

Geels, F., 2002. Technological transitions as evolutionary reconfiguration processes: a multi-level perspective and a case-study. Research Policy 31, 1257-1274.

Gibbons, A., 2010. Human Ancestors Were an Endangered Species [WWW Document]. ScienceNOW. URL http://news.sciencemag.org/sciencenow/2010/01/19-02.html

Godfrey, E.S., 1975. The development of English glassmaking: 1560-1640. Clarendon Press, Oxford.

Grübler, A., 2011. Energy transitions [WWW Document]. The Encyclopedia of Earth. URL http://www.eoearth.org/article/Energy_transitions 
Hannah, L., 1979. Electricity before Nationalisation. Macmillan, London.

Hughes, T.P., 1983. Networks of Power Electrification in Western Society, 1880-1930. Johns Hopkins University Press, Baltimore.

IEA, 2008. World Energy Outlook, Outlook. International Energy Agency, Paris.

IET, 2012. Arc lamps introduction [WWW Document]. The Institution of Engineering and Technology. URL www.theiet.org/resources/library/archives/exhibition/arc/intro.cfm

Jaccard, M.K., 2005. Sustainable Fossil Fuels: The Unusual Suspect in the Quest for Clean and Enduring Energy. Cambridge University Press, Cambridge.

Johnson, D.C., Kohler, T.A., Cowan, J.., 2004. Modeling multigenerational household response to fuelwood availability: Using long term data to help solve current problems, in: 69th Annual Meeting of the Society for American Archaeology.

Keeley, L., 1997. Frontier Warfare in the Early Neolithic, in: Martin, D.L., Frayer, D.W. (Eds.), Troubled Times: Violence and Warfare in the Past. OPA, pp. 303-320.

Keirstead, J., Samsatli, N., Shah, N., Weber, C., 2011. The impact of CHP (combined heat and power) planning restrictions on the efficiency of urban energy systems. Energy.

Kennedy, C., 2011. The Evolution of Great World Cities. University of Toronto Press, Toronto.

Kölbl, R., Helbing, D., 2003. Energy laws in human travel behaviour. New Journal of Physics 5, 48.1-48.12.

Leach, G., 1992. The energy transition. Energy Policy 20, 116-123.

MSSO, 2012. Dr James Young (1811-1883) [WWW Document]. Museum of the Scottish Shale Oil industry. URL http://www.scottishshale.co.uk/HistoryPages/Biographies/JamesYoung.html

Malanima, P., 2006. Energy crisis and growth 1650-1850: the European deviation in a comparative perspective. Journal of GLobal History 1, 101-121.

Malanima, P., Volckart, O.I., 2007. Urbanisation 1700-1870, in: Unifying European Experience: An Economic History of Modern Europe.

Mohammad, S., 2009. Urban, Peri-Urban, Slum Electrification: Kenyan Experience [WWW Document]. World Bank. URL

http://siteresources.worldbank.org/EXTAFRREGTOPENERGY/Resources/7173051264695610003/6743444-1268073502059/5.3.Kenya_periurban_electrification.pdf

Nissing, C., Blottnitz, H. von, 2010. Renewable energy for sustainable urban development: Redefining the concept of energisation. Energy Policy.

Parry, D., 2005. Engineering the Ancient World. Sutton Publishing.

Patterson, W., 1999. Transforming Electricity: The Coming Generation of Change. Earthscan, London. 
Postgate, J.N., 1994. Early Mesopotamia: society and economy at the dawn of history. Routledge, London.

Rackham, O., 2010. Woodlands. Collins.

Raleigh, V.S., 2000. Trends in world population: how will the millenium compare with the past? Human reproduction update 5, 500-5.

Samuels, M.L., Betancourt, J.L., 1982. Modeling the long term effects of fuelwood harvests on Pinyon-Juniper woodlands. Environmental Management 6, 505-515.

Shiman, D.R., 1993. Explaining the collapse of the British Electrical Supply Industry in the late 1880s: Gas versus Electric Lighting Prices. Business and Economic History 22, 318-327.

Sieferle, R.P., 2001. The Subterranean Forest: Energy Systems and the Industrial Revolution. White Horse Press.

Smil, V., 1994. Energy in World History. Westview Press Inc., Boulder.

Smil, V., 2010. Science, energy, ethics and civilization, in: Chiao, R.Y., Cohen, M.L., Leggett, A.J., Phillips, W.D., Harper Jr., C.L. (Eds.), Visions of Discovery: New Light on Physics, Cosmology, and Consciousness. Cambridge University Press, Cambridge, pp. 709-729.

Sorensen, B., 2011. A History of Energy: Northern Europe from the Stone Age to the Present Day. Routledge, London.

Sugihara, H., Komoto, J., Tsuji, K., 2004. A multi-objective optimization model for determining urban energy systems under integrated energy service in a specific area. Electrical Engineering in Japan 147, 20-31.

Tainter, J.A., 1988. The Collapse of Complex Societies. Cambridge University Press, Cambridge.

Tudge, C., 1998. Neanderthals, Bandits and Farmers: How agriculture really began. Weidenfield \& Nicolson, London.

Verbong, G., Geels, F., 2007. The ongoing energy transition: Lessons from a socio-technical, multilevel analysis of the Dutch electricity system (1960-2004). Energy Policy 35, 1025-1037.

WEC, 2010. Energy and Urban Innovation. London.

Weber, C., Shah, N., 2011. Optimisation based design of a district energy system for an eco-town in the United Kingdom. Energy 36, 1292-1308.

Williams, M., 2002. Deforesting the Earth: From Prehistory to Global Crisis. University of Chicago Press, Chicago.

Williams, T., 1981. A history of the British gas industry. Oxford University Press, Oxford.

Wolmar, C., 2004. The Subterranean Railway: How the London Underground Was Built and How it Changed the City Forever. Atlantic Books. 
Wrangham, R.W., Jones, J.H., Laden, G., Pilbeam, D., Conklin-Brittain, N., 1999. The Raw and the Stolen: Cooking and the Ecology of Human Origins. Current Anthropology 40, 567-594.

Wrigley, E.A., 2010. Energy and the English Industrial Revolution. Cambridge University Press, Cambridge. 
Table 1: Significant urban energy system transitions in the UK. Data from Raleigh (2000) and Gibbons (2010).

\begin{tabular}{|c|c|c|c|c|c|}
\hline Transition & Approx. date & $\begin{array}{l}\text { Approx. global } \\
\text { population }\end{array}$ & Driver & Technology & Consequence \\
\hline $\begin{array}{l}\text { Raw to cooked } \\
\text { food }\end{array}$ & $\begin{array}{l}1.2-2 \text { million } \\
\text { years ago }\end{array}$ & 20,000 & Food supply & Fire & Population increase \\
\hline $\begin{array}{l}\text { Nomadic to settled } \\
\text { lifestyle }\end{array}$ & $10,000 \mathrm{BC}$ & 10 million & Food security & Horticulture & Population increase \\
\hline Settled to Urban & $3000 \mathrm{BC}$ & 50 million & $\begin{array}{l}\text { Food security, trade and } \\
\text { defence }\end{array}$ & Agriculture, wheel and sail & City states and trade \\
\hline Biomass to coal & $1650 \mathrm{AD}$ & 500 million & Transport cost of wood fuel & Chimneys and steam & $\begin{array}{l}\text { Rapid urban } \\
\text { industrialization }\end{array}$ \\
\hline $\begin{array}{l}\text { Early urban } \\
\text { networks }\end{array}$ & $1850 \mathrm{AD}$ & 1.2 billion & Effective street lighting & $\begin{array}{l}\text { Incandescent light bulb; gas cooker; } \\
\text { railways }\end{array}$ & $\begin{array}{l}\text { Better energy services. } \\
\text { Suburbs and } \\
\text { commuting. }\end{array}$ \\
\hline National grids & $1950 \mathrm{AD}$ & 3 billion & $\begin{array}{l}\text { Efficiencies of scale and } \\
\text { natural gas discoveries }\end{array}$ & Electricity and gas grids, automobiles & $\begin{array}{l}\text { Low energy prices, } \\
\text { reduced dependence on } \\
\text { coal }\end{array}$ \\
\hline $\begin{array}{l}\text { Integrated energy } \\
\text { services? }\end{array}$ & $?$ & $\sim 9$ billion? & $\begin{array}{l}\text { System efficiency, resource } \\
\text { availability, climate } \\
\text { constraints }\end{array}$ & $\begin{array}{l}\text { Highly efficient use, integrated energy } \\
\text { systems, secure low emission supplies }\end{array}$ & $?$ \\
\hline
\end{tabular}




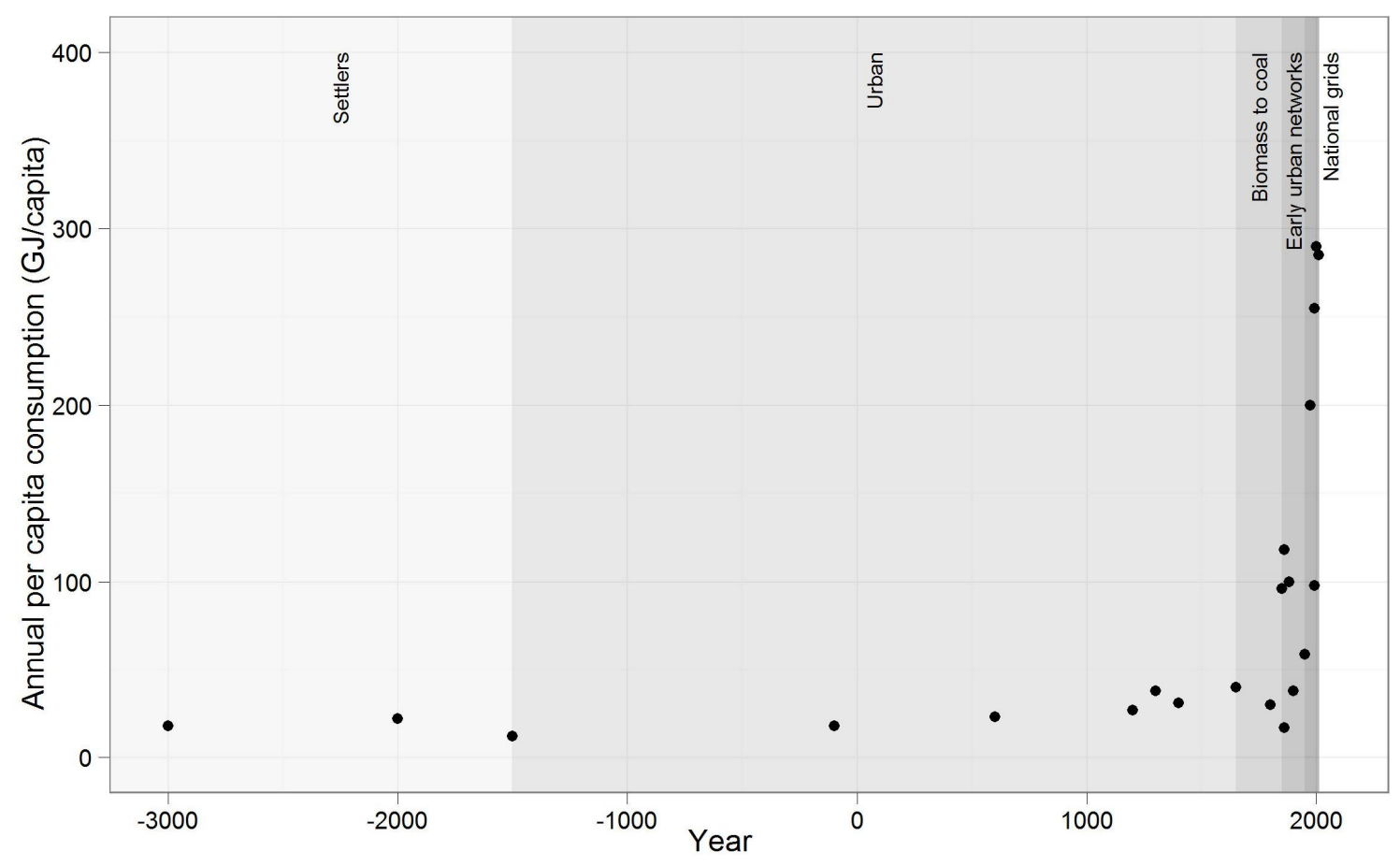

Figure 1: The rise in energy demand per capita as communities urbanized and then industrialized, switching from a biomass-fuelled energy system to fossil fuels around 400 years ago. Data from Smil (1994), Grübler (2011), and Sorensen (2011). 